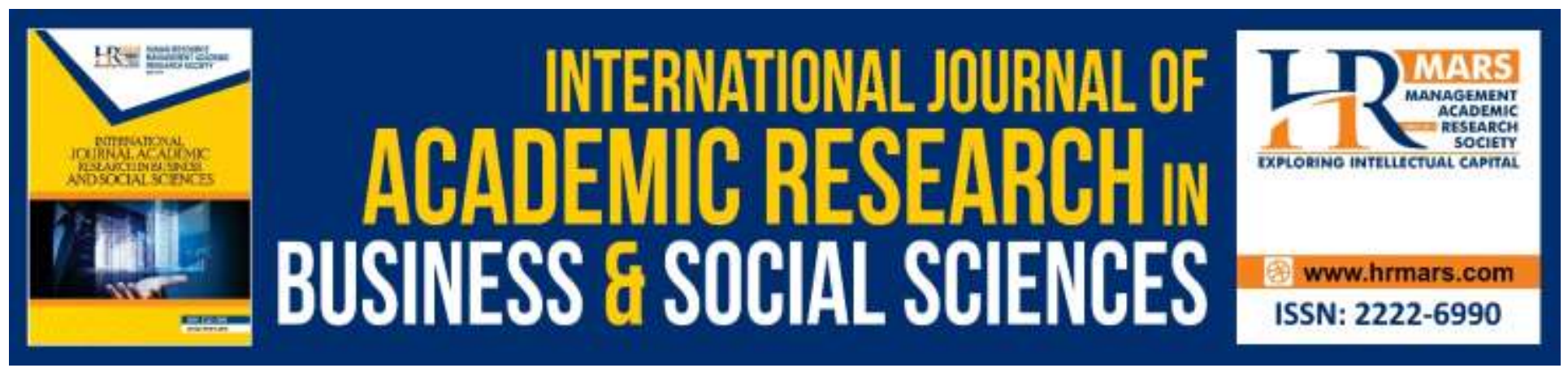

\title{
Performance of Small and Medium Enterprises in Ondo State, Nigeria: Does Application of Information and Communication Technology Make a Difference?
}

Simon-Oke O. Olayemi, Aderibaki O. Bolanle

To Link this Article: http://dx.doi.org/10.6007/IJARBSS/v10-i3/7089

DOI:10.6007/IJARBSS/v10-i3/7089

Received: 04 February 2020, Revised: 23 February 2020, Accepted: 15 March 2020

Published Online: 31 March 2020

In-Text Citation: (Olayemi \& Bolanle, 2020)

To Cite this Article: Olayemi, S.-O. O., \& Bolanle, A. O. (2020). Performance of Small and Medium Enterprises in Ondo State, Nigeria: Does Application of Information and Communication Technology Make a Difference? International Journal of Academic Research in Business and Social Sciences, 10(3), 749-760.

Copyright: (C) 2020 The Author(s)

Published by Human Resource Management Academic Research Society (www.hrmars.com)

This article is published under the Creative Commons Attribution (CC BY 4.0) license. Anyone may reproduce, distribute, translate and create derivative works of this article (for both commercial and non-commercial purposes), subject to full attribution to the original publication and authors. The full terms of this license may be seen at: http://creativecommons.org/licences/by/4.0/legalcode

Vol. 10, No. 3, 2020, Pg. 749 - 760

http://hrmars.com/index.php/pages/detail/IJARBSS

JOURNAL HOMEPAGE

Full Terms \& Conditions of access and use can be found at http://hrmars.com/index.php/pages/detail/publication-ethics 


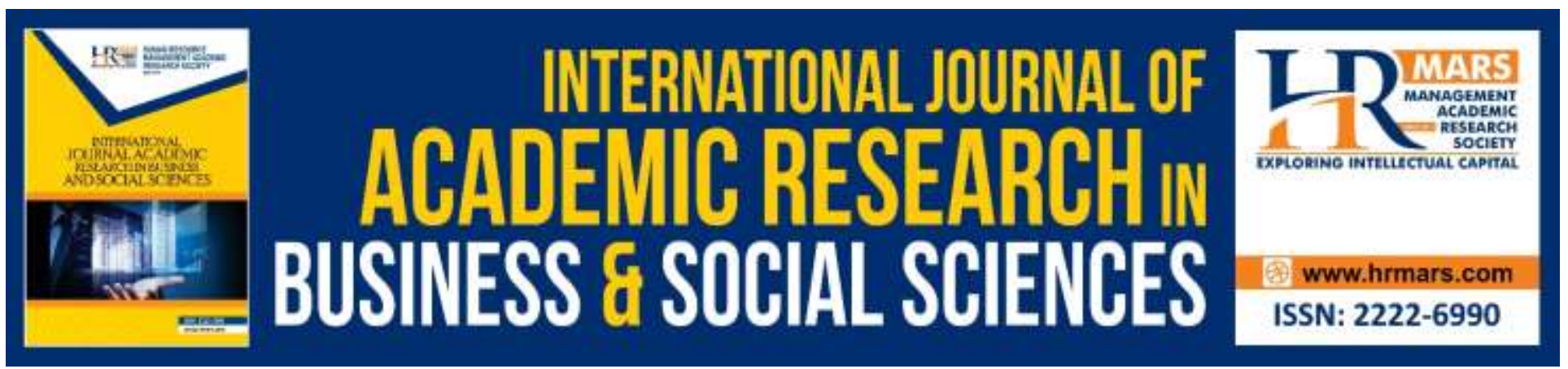

\title{
Performance of Small and Medium Enterprises in Ondo State, Nigeria: Does Application of Information and Communication Technology Make a Difference?
}

\author{
Simon-Oke O. Olayemi ${ }^{1}$, Aderibaki O. Bolanle ${ }^{2}$ \\ ${ }^{1}$ Department of Economics, Federal University of Technology, Akure, Nigeria, ${ }^{2}$ Departments of \\ Business Administration, Federal University of Technology,Akure, Nigeria \\ Email: oosimon-oke@futa.edu.ng ${ }^{1}$ faloyobolanle@gmail².
}

\begin{abstract}
In spite of the roles played by ICT and the various efforts made by government at all levels to encourage SMEs to adopt ICT for effective performance, SMEs in Nigeria have failed to take the advantage of reaping the benefits of ICT application in order to perform optimally. The study therefore investigated the extent of ICT application by Small and Medium Enterprises, and evaluates the effect of ICT application on the performance of SMEs in Ondo State, using a well-structured questionnaire as method of data collection. Both descriptive and inferential methods of analysis were also used by the study. The descriptive analysis revealed that SMEs applied ICT devices to a large extent in their operations in the study area; leaving only the satellite system (2.03), cash counting machine (2.02), fax/telex (1.90) and Cash tiling machine (1.58) devices that were 'not often' or 'never' used, with their corresponding mean values within $1.81-2.6$ and $1.0-1.8$ respectively. The Hierarchical Multiple Regression and Analysis of Variance (ANOVA) results also indicated positive and significant effect of ICT application on performance of SMEs in the study area, with all the predictor models significant at 5\% level. The study concluded that ICT application did not just make a difference but a significant difference in the performance of small and medium enterprises (SMEs) in Ondo State, Nigeria; while also recommended the need to put into constant use some of the ICT devices that were not often or 'never' used by SMEs, so as to continually serve the customers better, gaining competitive advantage and maintaining significant performance of SMEs in Ondo State, Nigeria.
\end{abstract}

Keywords: Performance, ICT Application, SMEs, Ondo State, Nigeria.

\section{Introduction}

Businesses in Nigeria have been categorized as Small, Medium and Large, both in developed and developing countries (Ayozie, Jacob, Umukoro and Ayozie, 2013). It is a well-known fact globally that Small and Medium Enterprises sector is a key engine to economic growth and development 
INTERNATIONAL JOURNAL OF ACADEMIC RESEARCH IN BUSINESS AND SOCIAL SCIENCES Vol. 10, No. 3, March, 2020, E-ISSN: 2222-6990 @ 2020 HRMARS

(SMEDAN, 2017). The dynamic nature of this sector also makes it vulnerable to high mortality rate occasioned by sudden shifts in economic policy, global trends, global shocks in international markets and many unforeseen situations. The lean nature and size of this sector, which highlights its vulnerability, is also its key asset. It is flexible and can easily rise up to and adapt to sudden change both locally and globally (SMEDAN, 2017). Therefore, the attention of government at all levels is shifting towards small and medium enterprises as a means of economic development and a real mean of solving problems, also as a seedbed of innovations, inventions and employment generation (Ayozie et al., 2013). The contribution of small and medium enterprises has been recognized as main sustenance of the economy because of its capacity in enhancing output (GDP) and human capacity of the country (Kuyoro, Awodele, Alao and Omotunde, 2013). SMEs have also become so important in enabling the country to attain their developmental objectives, notably poverty alleviation and wealth creation. These desire objectives can be efficiently achieved by SMEs especially in the developing economies through application of sophisticated Information and Communication Technologies (ICT) to drive optimum business performance (Kuyoro et al., 2013).

Meanwhile, the information and communication technology (ICT) as broadly defined by David and Bernard (2018) as a field of information processing and communication through the use of computing devices, computer programs and also telecommunication equipment and techniques. Thus, ICTs can be viewed as a collective term for a wide range of software, hardware, telecommunications and information management techniques, applications and devices, and are used to construct, produce, evaluate, process, package, distribute, receive, retrieve, store and transform information. The ICT application for SMEs development according to OECD (2011) includes mobile phone, email, laptop, smart cards, printer, photocopier, point of sales (POS), scanner, cash counting machine, fax/telex, cash tilling machine, internet, data storage, network security device, communication satellite and enterprise application system (EAS) among others. The Information and Communication Technology (ICT) is treasured to drive small and medium enterprises to greater and efficient performance as it provides the opportunity for SMEs to be in any location across the globe (Oyedele, Kareem and Akanbi, 2016). Therefore, the application of ICT tools is very crucial to SMEs because it constitutes a major facilitator and enabler of structural change (Kuyoro et al., 2013). However, SME in Nigeria have limited capacity to apply the latest information and communication technology especially in the local communities (Onyeaghala and Anele, 2014; National MSME Survey Report, 2017), which often responsible for inability of most SMEs to effectively take advantage of available potential market occasioned by 'digital divide' which characterizes developing countries. This digital divide is the gap between the accomplished and unaccomplished roles of ICT (Kuyoro et al., 2013).

Although, ICT is one of the key ingredients to the performance, growth, survival and sparkling enterprises, but its acceptance and use by SMEs in many communities in Nigeria is below expectations (Fatusin and Oladehinde, 2018). Similarly, despite numerous efforts made by government at all levels to encourage SMEs to adopt ICT, it has been so difficult for many of the SMES to embrace ICT and enjoy its benefits, due to number of hindering factors such as lack of awareness of the available ICT tools, lack of skilled personnel, lack of social factors that can influence the adoption pattern among others (Wambaria, Kibas and Asienga, 2016). Regardless of the acknowledged benefits attached to the use of ICT by organizations, numerous studies still reported relatively low level of adoption and perceived ease of using ICT facilities among SMEs in Nigeria compared to developed countries, due to lack of capacity to finance and sustain it (Ghobakhloo, 
Hong, Sabouri and Zulkifli, 2011; David and Bernard, 2018). Some studies also identified number of reasons why some SMEs failed to apply some ICT tools such as inadequate finances, lack of awareness of the available ICT tools in the market, lack of technical know- how, lack of skilled personnel, and limited access to market information among others (MacGregor, Vrazalic, Calsson, Bunker and Magnusson, 2012). Also, management techniques such as financial analysis, forecasting and project management skills are rarely used by SMEs; therefore, application of ICT by SMEs is at a drawback (MacGregor et al., 2012). Other hindrances to the application of ICT solutions by SMEs in the context of extant studies from Nigeria, which include but not limited to the following: Poor adoption of e-business models created in developed nations by business owners, lack of constant electricity, high cost of ICT implementation, unfriendly government policies and intervention as well as low literacy level among others (Apulu and Latham, 2009; Apulu and Ige, 2011).

Despite the identified reasons for non-application of ICT tools by many SMEs, evidences still abound from business practices across the world that taking the advantage of information and communication technology, diffusion is possible for business organizations and adoption of ICT can provide organizations with valuable information for improved performance, improved relationships with customers and suppliers, increased efficiency and reduced production cost; while only the fullsize businesses could seize the opportunity of ICT application to gain the advantage over their competitors unlike the small and medium enterprises (Akande and Yinus, 2013). Although, ICT is one of the key ingredients to the performance, growth, survival and sparkling enterprises but its application and continuous use by most SMEs in Nigeria, particularly Ondo State is below expectation (Fatusin and Oladehinde, 2018). Similarly, despite the important roles played by ICT and various efforts made by government at all levels to encourage SMEs to adopt ICT in their operations, it has been reported that SMEs have been epileptic due to various factors hindering the sector from enjoying the benefits of ICT in order to make a significant difference in the economy (Wambaria et al., 2016).

Based on the stated facts, the study broadly investigates the application of Information and communication technology (ICT) and performance of SMEs in Ondo State, Nigeria; and specifically seeks to:

(i) examine the extent of ICT application by Small and Medium Enterprises in Ondo State, Nigeria; and (ii) evaluate the effect of ICT application on the performance of SMEs in the study area.

This study was informed by the intending benefits of ICT applications, which continue to remain a mirage to many of the SMEs especially in Nigeria because of their non ICT compliance. This situation has placed many of the SMEs at disadvantage position to experience a wide range of organizational structure leading to optimum performance of the sector in Nigeria.

\section{Research Method}

\section{Conceptual Framework}

The study framework was developed as a modified hybrid of the Unified Theory of Acceptance and Use of Technology(UTAUT) by Venkatesh et al. (2003). The theory was also developed into a model shown in Fig.1,in which Quality, Cost, Speed, Dependability and Flexibility were used as measures of SMEs performance which represent the dependent variable while various ICT products used by SMES were considered as measure of ICT application, and as explanatory variable; which also work together 
INTERNATIONAL JOURNAL OF ACADEMIC RESEARCH IN BUSINESS AND SOCIAL SCIENCES Vol. 10, No. 3, March, 2020, E-ISSN: 2222-6990 ¿ 2020 HRMARS

with the intervening factors like Performance Expectancy, Effort Expectancy, Social Expectancy/Influence and facilitating conditions to determine the performance of SMEs.

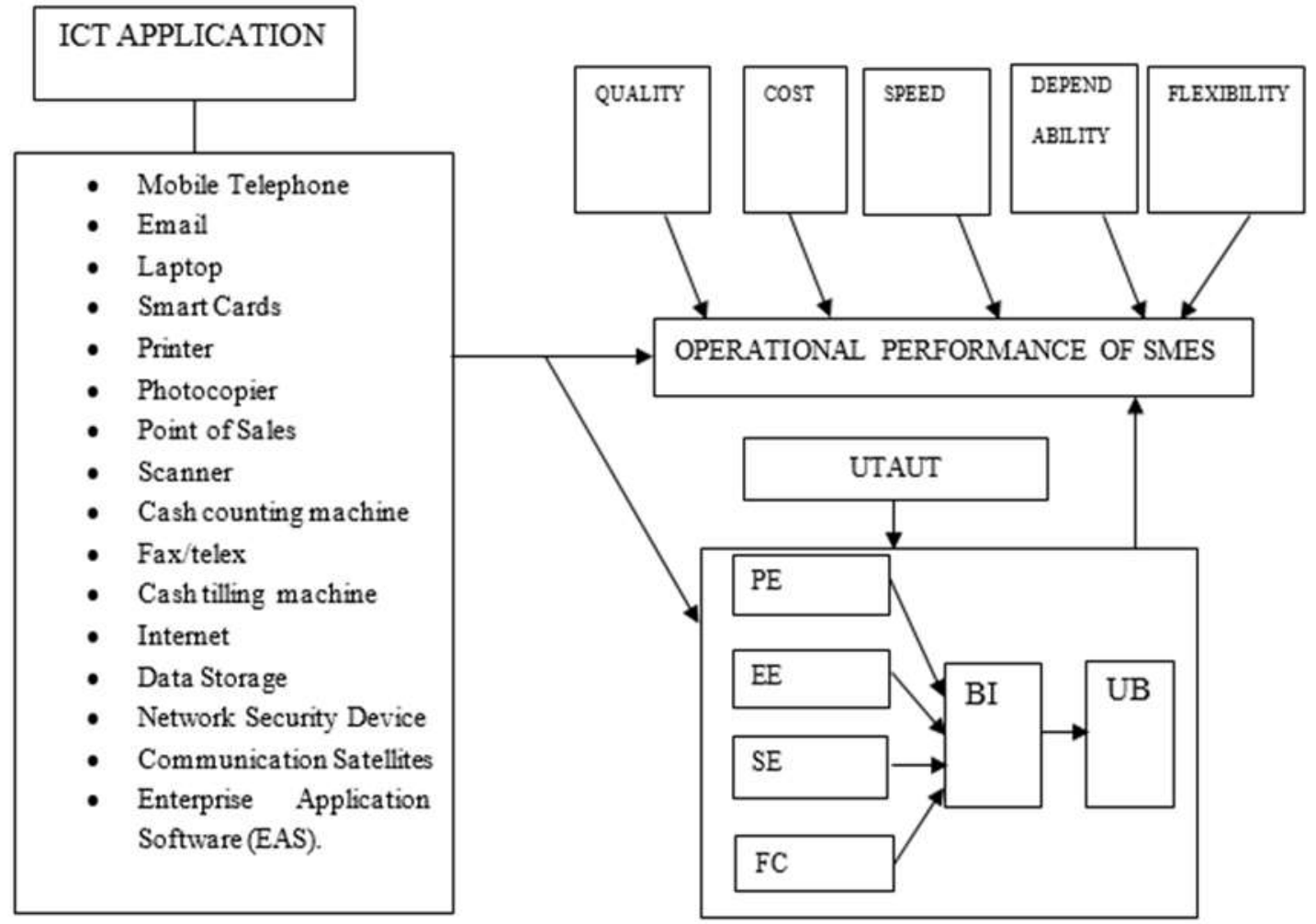

$\mathrm{PE}=$ Performance Expectancy; $\mathrm{EE}=\mathrm{Effort}$ Expectancy; $\mathrm{SE}=$ Social Expectancy/influence

$\mathrm{FC}=$ Facilitating Conditions; $\mathrm{BI}=$ Behavioral Intention; UB=Use Behavior

Figure1: Conceptual Framework

Source: Venkatesh et al. (2003)

\section{Research Design and Study Area}

This study adopts a descriptive survey type with a cross sectional measurement of likely effect of ICT application on the performance of SMEs using primary data; while the study was carried out in Ondo State, South-West, Nigeria, which was created on 3rd February, 1976 with a geographical area of 15,500sq km. The state accommodates a population of over 3,460,877 (updated from NPC 2006 estimate) who are mainly Yorubas', the dominant tribe in South-Western Nigeria. Ondo State borders Ekiti state to the north, Kogi State to the northeast, Edo State to the east, Delta State to the southeast, Ogun State to the southwest, and Osun State to the northwest. The state has eighteen local government areas with three senatorial districts which are Ondo Central,Ondo South and Ondo North while the local government areas include Akoko North-East, Akoko North-West, Akoko South-East, Akoko South-West, Akure North, Akure South, Ese Odo, Idanre, Ifedore, Ilaje, Ile Oluji/Okeigb, Irele, Odigbo, Okitipupa, Ondo East, Ondo West, Ose and Owo.The major occupations of the citizens are civil service, agricultural activities and other business enterprises across the state. The state also play host to prominent federal, state and private higher institutions. 
INTERNATIONAL JOURNAL OF ACADEMIC RESEARCH IN BUSINESS AND SOCIAL SCIENCES Vol. 10, No. 3, March, 2020, E-ISSN: 2222-6990 @ 2020 HRMARS

\section{Population, Sample and Sampling Procedure}

The target population involved in the study comprises the entire owners/managers of Small and medium enterprises (SMEs) in Ondo State. Therefore a total figure of one thousand, nine hundred and ninety-nine $(1,999)$ owners/managers of SMEs were identified and obtained as at 2018 from the Small and Medium Enterprises Development Agency in Ondo State. In order to make the study a representative of the entire State, three (3) local government areas were selected namely Akure South, Okitipupa, Akoko South-West, which was informed by the present of prominent tertiary institutions which attracted many people to the areas probably for business reason. Meanwhile, the sample size of two hundred (200) SMEs were selected out of total population of one thousand, nine hundred and ninety-nine $(1,999)$ registered SMEs using random purposive sampling procedure. This constitutes $10 \%$ of the entire sample frame (Agbola, Egunjobi, Olatubara, Yusuf and Alabi, 2003).

\section{Data Collection Method and Questionnaire Administration}

The study data collection method was through primary with a well-structured questionnaire to elicit information from the respondents. The design of the questionnaire was adopted from the study of Simon-Oke (2020). Two hundred copies (200) of the questionnaire were distributed and administered on the owners / managers of SMEs in the selected areas based on the number of registered SMEs in each area. One hundred and twenty (120) copies of questionnaire were administered in Akure South, fifty copies (50) in Okitipupa while the remaining thirty (30) copies were administered in Akoko SouthWest respectively. Out of the total questionnaire (200 copies) administered, One hundred and ninetyone (191) useful responses were retrieved and used to arrive at the findings of the study. This constitutes 95.5 per cent of the sample size.

\section{Method of Data Analysis}

Both descriptive (simple percentages, frequency distribution tables and mean ranking) and inferential (Hierarchical Multiple Regression) statistics were considered as analytical tools of the study, using SPSS 23 (Statistical Package for Social Science) at 5\% (0.05) level of significant and 95\% confidence level.

\section{Results and Discussion}

The study specifically seeks to investigate the extent of ICT application by Small and Medium Enterprises and evaluate the effect of ICT application on the performance of SMEs in Ondo State. These objectives were subjected to various analytical tools for possible study outcomes and discussion.

\section{Extent of ICT Application by Small and Medium Enterprises in Ondo State}

The objective of examining the extent of ICT application by Small and Medium Enterprises in the study area was achieved using both simple percentages and mean ranking. Table1 and Table 2 confirmed the extensive application of ICT devices by SMEs in the study area. Table 1 shows that all the respondents except (5) $2.6 \%$ were familiar to a large extent with the use of computer, internet and other electronic devices. This implies that almost all the respondents have been using this infrastructure in one way or the other for personal use or otherwise. Therefore, it is unlikely for SMEs operators to find it difficult to apply ICT devices in their businesses. This result was also supported by 
INTERNATIONAL JOURNAL OF ACADEMIC RESEARCH IN BUSINESS AND SOCIAL SCIENCES Vol. 10, No. 3, March, 2020, E-ISSN: 2222-6990 @ 2020 HRMARS

the study of Olise, Anigbogu, Edoko and Okoli (2014); Ramoni and Adepoju, (2018) who found a significant difference in the levels of awareness and adoption patterns of ICT facilities among SMEs. Table 2 also represents the opinion of the respondents on the application of ICT devices by Small and Medium Enterprises in the study area. It is evident from Table 2 that the use of telephone or mobile phone occupies a prominent position among SMEs in the study area. It was ranked first among the entire examined ICT infrastructure and has a mean value of 4.60 which means phone was 'very often used' by the SMEs. The introduction of phone has changed the way businesses are being run in the study area. Internet facilities and laptops were also applied very often by SMEs and they occupy the second and third positions with mean values of 3.81 and 3.54 respectively. These values are within the range 3.40-4.20 which connotes consistency in the application of the devices. With internet access on both phone and laptop, transactions involving electronic funds transfer can be carried out. Smart cards with mean value of 3.45 occupy the fourth position in term of ICT application by the SMEs and were 'very often' used as indicated by the respondents. The device is normally used for the purpose of storing information relating to the business and used on computer related devices. Also, the following ICT devices with their corresponding mean values: printer (3.27), photocopier (3.17), Point of Sales (POS) (3.14), scanner (3.04), data storage and security devices (2.85), network security system (2.70) and enterprise application software (2.66) were normally used by the SMEs at moderate levels (often) compare to the earlier ranked devices considering their mean values within 2.61-3.40. Printer, photocopier, scanner and data storage and security devices were used for business information processing and storage. Point of Sales (POS) was used only for financial transactions while typical enterprise application software was applied for analyzing financial information for effective business decision making. Furthermore, it can be deduced from Table 2 that satellite system (2.03), cash counting machine (2.02) and fax/telex (1.90) were 'not often' used since their mean values are within $1.81-2.6$, even as Cash tiling machine (1.58) was 'never' used by SMEs in the study area since its mean is within $1.0-1.8$. These were the four least ranked and rarely used ICT devices by SMEs in the study area.

Table 1: Respondents' distribution based on familiarization with the use of ICT devices by SMEs in the study area

\begin{tabular}{lll}
\hline Response & Frequency & Percent \\
\hline Yes & 186 & 97.4 \\
No & 5 & 2.6 \\
Total & 191 & 100.0 \\
\hline
\end{tabular}

Source: Field Survey Data Computation, 2019 
INTERNATIONAL JOURNAL OF ACADEMIC RESEARCH IN BUSINESS AND SOCIAL SCIENCES

Vol. 10, No. 3, March, 2020, E-ISSN: 2222-6990 C 2020 HRMARS

Table 2: Respondents' Distribution Based on Application of ICT Devices by SMEs in the Study Area

\begin{tabular}{|c|c|c|c|c|c|c|c|c|c|c|c|c|c|}
\hline & \multicolumn{2}{|c|}{ Manufacturin } & \multicolumn{4}{|c|}{$\begin{array}{l}\text { PharmaceuticlCT } \\
\text { al }\end{array}$} & \multicolumn{2}{|c|}{$\begin{array}{l}\text { Food \& } \\
\text { Beverages }\end{array}$} & \multicolumn{2}{|c|}{ Others } & \multicolumn{2}{|l|}{ All } & \\
\hline & Mean & Rank & $\begin{array}{l}\text { Mea } \\
\mathrm{n}\end{array}$ & Rank & $\begin{array}{l}\text { Mea } \\
\mathrm{n}\end{array}$ & Rank & $\begin{array}{l}\text { Mea } \\
n\end{array}$ & Rank & $\begin{array}{l}\text { Mea } \\
n\end{array}$ & Rank & $\begin{array}{l}\text { Mea } \\
n\end{array}$ & $\begin{array}{l}\text { Ran } \\
\mathrm{k}\end{array}$ & \\
\hline Telephone & 4.72 & 1 & 4.70 & 1 & 4.70 & 1 & 4.41 & 1 & 4.56 & 1 & 4.60 & 1 & VMO \\
\hline Internet & 3.48 & 3 & 4.22 & 2 & 4.40 & 2 & 3.25 & 2 & 3.69 & 2 & 3.81 & 2 & VO \\
\hline Laptop & 3.28 & 4 & 4.22 & 3 & 4.40 & 3 & 2.78 & 6 & 3.22 & 5 & 3.54 & 3 & VO \\
\hline Smart cards & 3.68 & 2 & 3.51 & 10 & 3.47 & 9 & 3.13 & 3 & 3.46 & 3 & 3.45 & 4 & VO \\
\hline Email address & 3.08 & 5 & 3.76 & 8 & 3.87 & 7 & 3.06 & 5 & 3.35 & 4 & 3.43 & 5 & VO \\
\hline Printer & 2.88 & 6 & 4.08 & 4 & 4.33 & 4 & 2.34 & 7 & 2.91 & 6 & 3.27 & 6 & $\mathrm{O}$ \\
\hline Photocopier & 2.80 & 9 & 3.84 & 6 & 4.23 & 5 & 2.22 & 8 & 2.88 & 7 & 3.17 & 7 & $\mathrm{O}$ \\
\hline Point of Sales (POS) & 2.84 & 7 & 3.78 & 7 & 3.43 & 10 & 3.13 & 4 & 2.82 & 8 & 3.15 & 8 & $\mathrm{O}$ \\
\hline Scal & 2.80 & 8 & 3.86 & 5 & 4.17 & 6 & 2.13 & 10 & 2.59 & 10 & 3.04 & 9 & $\mathrm{O}$ \\
\hline $\begin{array}{l}\text { Data storage \& } \\
\text { security devices }\end{array}$ & 2.52 & 10 & 3.43 & 11 & 3.70 & 8 & 2.16 & 9 & 2.59 & 9 & 2.85 & 10 & $\mathrm{O}$ \\
\hline $\begin{array}{l}\text { Network security } \\
\text { system }\end{array}$ & 2.36 & 12 & 3.35 & 12 & 3.37 & 11 & 2.00 & 13 & 2.49 & 11 & 2.70 & 11 & $\mathrm{O}$ \\
\hline $\begin{array}{l}\text { Enterprise } \\
\text { application software }\end{array}$ & 2.32 & 13 & 3.59 & 9 & 3.33 & 12 & 1.97 & 14 & 2.29 & 12 & 2.66 & 12 & $\mathrm{O}$ \\
\hline Satellite system & 2.28 & 14 & 2.27 & 14 & 1.47 & 15 & 2.06 & 11 & 2.04 & 13 & 2.04 & 13 & NO \\
\hline $\begin{array}{l}\text { Cash counting } \\
\text { machine }\end{array}$ & 1.92 & 15 & 2.68 & 13 & 2.17 & 13 & 2.03 & 12 & 1.62 & 15 & 2.02 & 14 & NO \\
\hline Fax/Telex & 2.40 & 11 & 2.16 & 15 & 1.83 & 14 & 1.69 & 15 & 1.68 & 14 & 1.90 & 15 & NO \\
\hline Cash tiling machine & 1.72 & 16 & 1.89 & 16 & 1.27 & 16 & 1.59 & 16 & 1.47 & 16 & 1.58 & 16 & $\mathrm{~N}$ \\
\hline
\end{tabular}

Interpretation of Mean Rank: Very much often $(\mathrm{VMO})=4.21-5.00$, Very often $(\mathrm{VO})=3.4-4.20$, Often $(O)=2.61-3.4$, Not Often $(N O)=1.81-2.6$, Never $(N)=1.0-1.8$

Source: Field Survey Data Computation, 2019

Effect of Information and Communication Technology (ICT) Application on Performance of Small and Medium Enterprises (SMEs) in Ondo State

Table 3 shows the effect of ICT application on the performance of SMEs in the study area using the Hierarchical Multiple Regression. The Table shows the analysis of five different models with their corresponding predictor variables. All the models with the respective predictor variables (ICT application, performance expectation, effort expectancy, social expectation/influence and facilitating conditions) recorded positive correlation with each other $(r=0.411,0.556,0.614,0.631,0.653$ respectively), while $\mathrm{R}^{2}$ in the respective models explained the variation of $16.9 \%, 30.9 \%, 37.7 \%$, $39.9 \%$, and $42.6 \%$ respectively in the performance of SMEs occasioned by the application of ICT in the study area. All the models with their respective predictor variables were also statistically 
INTERNATIONAL JOURNAL OF ACADEMIC RESEARCH IN BUSINESS AND SOCIAL SCIENCES Vol. 10, No. 3, March, 2020, E-ISSN: 2222-6990 @ 2020 HRMARS

significant with $\mathrm{F}$ statistic values of $38.3,38.2,20.4,16.6$ and 18.9 respectively, and less than $5 \%$ significant level. This implies that all the predictor variables in the models (ICT Application, performance expectation, effort expectancy, social expectation/influence and facilitating conditions) contributed significantly to the performance of SMEs in the study area.

Table 3: The Model Summary of the Hierarchical Multiple Regression

\begin{tabular}{|c|c|c|c|c|c|c|c|c|c|}
\hline \multirow[t]{4}{*}{ Model } & \multirow[t]{4}{*}{$r$} & $R$ & Adjusted & Std. & \multicolumn{5}{|c|}{ Change Statistics } \\
\hline & & \multirow[t]{3}{*}{ Square } & \multirow[t]{3}{*}{ R Square } & Error of & $\mathrm{R}$ & & & & \\
\hline & & & & & Square & $\mathrm{F}$ & & & Sig. $F$ \\
\hline & & & & Estimate & Change & Change & df1 & df2 & Change \\
\hline 1 & $.411 a$ & .169 & .164 & 6.60125 & .169 & 38.316 & 1 & 189 & .000 \\
\hline 2 & $.556 b$ & .309 & .302 & 6.03333 & .141 & 38.256 & 1 & 188 & .000 \\
\hline 3 & $.614 c$ & .377 & .367 & 5.74326 & .068 & 20.470 & 1 & 187 & .000 \\
\hline 4 & $.631 d$ & .399 & .386 & 5.65858 & .021 & 16.639 & 1 & 186 & .001 \\
\hline 5 & $.653 e$ & .426 & .411 & 5.54164 & .028 & 18.932 & 1 & 185 & .003 \\
\hline
\end{tabular}

a. Predictors: (Constant), Application, Performance Expectation

b. Predictors: (Constant), Application, Performance Expectation, Effort Expectancy

c. Predictors: (Constant), Application, Performance Expectation, Effort Expectancy

d. Predictors: (Constant), Application, Performance Expectation, Effort Expectancy, Social Influence

e. Predictors: (Constant), Application, Performance Expectation, Effort Expectancy, Social Influence, Facilitating Conditions

f. Dependent Variable: Performance

Source: Field Survey Data Computation, 2019

\section{Test of Study Hypothesis}

The study considered testing the following hypothesis:

$\mathrm{H}_{0}$ : ICT application has no significant effect on the performance of SMEs in Ondo State; using Analysis of Variance (ANOVA) test. Meanwhile, Table 4 indicates the result of ANOVA test showing the level of significance of each of the five models (one predictor, two predictors, three predictors, four predictors and five predictors respectively). All the five models were significant at $F(1,189)=38.316, p(.000)<0.05 ; \quad F(2,188)=42.062, p(.000)<0.05 ; \quad F(3,187)=37.769, p(.000)<0.05$; $\mathrm{F}(4,186)=30.841, \mathrm{p}(.000)<0.05$ and $\mathrm{F}(5,185)=27.511, \mathrm{p}(.000)<0.05$ respectively) at $5 \%$ level. The $F$ values show the predictive effect of ICT application on the performance of SMEs after controlling for performance expectation, effort expectancy, social expectation/influence and facilitating conditions respectively. The respective $\mathrm{F}$ values in Table 4 represent the overall predictive effects of each of the models; while each of the models also show a significant value of less than $5 \%$. This predicts a statistically significant effect of ICT application on performance of SMEs in the study area. Hence, the null hypothesis was rejected, and therefore affirmed that ICT application has significant effect on the performance of SMEs in the study area. This also implies that, the application of ICT has improved the performance of SMEs in the study area. This corroborates the findings of Akande and Yinus (2013); Yinus, Oladejo and Akande (2014) that ICT has a positive effect on the performance of selected Small and Medium Scale food, fruit drink and Beverages Firms operation in Nigeria. 
INTERNATIONAL JOURNAL OF ACADEMIC RESEARCH IN BUSINESS AND SOCIAL SCIENCES Vol. 10, No. 3, March, 2020, E-ISSN: 2222-6990 @ 2020 HRMARS

Table 4: The Result of Analysis of Variance (ANOVA ${ }^{\text {a) }}$ Test

\begin{tabular}{|c|c|c|c|c|c|c|}
\hline \multicolumn{2}{|c|}{ Model } & Sum of Squares & Df & Mean Square & $\mathrm{F}$ & Sig. \\
\hline \multirow[t]{3}{*}{1} & Regression & 1669.659 & 1 & 1669.659 & 38.316 & $.000^{\mathrm{b}}$ \\
\hline & Residual & 8235.964 & 189 & 43.577 & & \\
\hline & Total & 9905.623 & 190 & & & \\
\hline \multirow[t]{3}{*}{2} & Regression & 3062.227 & 2 & 1531.113 & 42.062 & $.000^{c}$ \\
\hline & Residual & 6843.396 & 188 & 36.401 & & \\
\hline & Total & 9905.623 & 190 & & & \\
\hline \multirow[t]{3}{*}{3} & Regression & 3737.426 & 3 & 1245.809 & 37.769 & $.000^{\mathrm{d}}$ \\
\hline & Residual & 6168.198 & 187 & 32.985 & & \\
\hline & Total & 9905.623 & 190 & & & \\
\hline \multirow[t]{3}{*}{4} & Regression & 3950.000 & 4 & 987.500 & 30.841 & $.000^{\mathrm{e}}$ \\
\hline & Residual & 5955.623 & 186 & 32.019 & & \\
\hline & Total & 9905.623 & 190 & & & \\
\hline \multirow[t]{3}{*}{5} & Regression & 4224.308 & 5 & 844.862 & 27.511 & $.000^{f}$ \\
\hline & Residual & 5681.315 & 185 & 30.710 & & \\
\hline & Total & 9905.623 & 190 & & & \\
\hline
\end{tabular}

a. Dependent Variable: Performance

b. Predictors: (Constant), Application

c. Predictors: (Constant), Application, Performance Expectation

d. Predictors: (Constant), Application, Performance Expectation, Effort Expectancy

e. Predictors: (Constant), Application, Performance Expectation, Effort Expectancy, Social

Influence

f. Predictors: (Constant), Application, Performance Expectation, Effort Expectancy, Social Influence, Facilitating Conditions

Source: Field Survey Data Computation, 2019

\section{Conclusion and Recommendation}

This study broadly investigates the application of Information and Communication Technology (ICT) and performance of Small and Medium Enterprises (SMEs) in Ondo State, Nigeria; while specifically seeks to examine the extent of ICT application by Small and Medium Enterprises, as well as evaluating the effect of ICT application on the performance of SMEs in the study area. The study, with the use of both descriptive and inferential statistics discovered that ICT devices were relatively engaged to a large extent by SMEs in the study area. Also, positive and significant effects of ICT application on the performance of SMEs were established. Based on these findings, the study concludes that application of ICT gained an extensive familiarity among SMEs operators and contributed positively and significantly to the sector in the study area. Consequently, ICT application did not just make a difference but a significant difference in the performance of small and medium enterprises (SMEs) in Ondo State. The study recommends among others the need to put into constant use some of the ICT devices such as satellite system, cash counting machine and fax/telex that were not often used by 
INTERNATIONAL JOURNAL OF ACADEMIC RESEARCH IN BUSINESS AND SOCIAL SCIENCES

Vol. 10, No. 3, March, 2020, E-ISSN: 2222-6990 C 2020 HRMARS

SMEs, so as to continually serve the customers better, gaining competitive advantage and maintaining significant performance of SMEs in Ondo State, Nigeria.

\section{Contribution to Knowledge}

Apart from supporting the existing studies on the possibility of engaging ICT devices by SMEs, the study also provided insight into the inherent potentials and wide range of benefits available to SMEs for adopting ICT in the study area. This further established the fact that application of ICT meant for improved performance of businesses is not only limited to large or corporate organizations but also extended to SMEs. These among others were considered as novelty of the study.

\section{References}

Agbola, T., Egunjobi, L., Olatubara, C. O., Yusuf, O. D., \& Alabi, M. (2003). Contemporary Social Science Research Methods: A Practical Guide. Nigeria: MURLAB Search wisdom Educational Services, p.133.

Akande, O., \& Yinus, O. (2013). An Appraisal of the Impact of Information Technology (IT) on Nigeria Small and Medium Enterprises (SMEs) Performance. International Journal of Academic Research in Management, 2(4), 140- 152.

Apulu, I., \& Ige, E. O. (2011). Are Nigeria SMEs Effectively Utilizing ICT? International Journal of Business and Management, 6(6), 207-214.

Apulu, I., \& Latham, A. (2009). “Knowledge Management: Facilitator for SME's Competitiveness in Nigeria."UK Academy for information systems Conference Proceedings, 2009.6

Ayozie, D. O., Jacob, S. O., Umukoro, F., \& Ayozie, V. U. (2013). Small and Medium Scale Enterprises (SMES) in Nigeria: The marketing interface. Global Journal of Management and Business Research Marketing, 13(9), 1-13.

David, S. C., \& Bernard, K. N. (2018). Influence of ICT Adoption on Small and Medium Enterprises Performance in the Entertainment Sector. ResearchJournali's Journal of Entrepreneurship, 5(2), 6-33.

Fatusin, A. F., \& Oladehinde, G. J. (2018). Implication of ICT Use on Productivity and Regional Development Planning Among Small Scale Enterprises in Ondo State. Agricultural and Resource Economic International Scientific E-Journal, 4(1), 5-19.

Ghobakhloo, M., Sabouri, M. S., Hong, T. S., \& Zulkifli, N. (2011). Information Technology Adoption in Small and Medium Sized Enterprises: An Appraisal of Two Decades Literature. Interdisciplinary Journal of research in Business, 1(7), 53-80.

Kuyoro, S. O., Awodele, O., Alao, O. D., \& Omotunde, A. A. (2013). ICT Solution to Small and Medium Scale Enterprises (SMEs) in Nigeria. International Journal of Computer and Information Technology, 4(2), 785-789.

MacGregor, R. C., Vrazalic, L., Carlsson, S., Bunker., \& Magnusson. (2012). The Impact of Business Size and Business Type on Small and Business Investment in Electronic Commerce: A Study of Swedish Small Businesses. Australasian Journal of Information System, 9(2), 31- 39.

Organisation of Economic Cooperation and Development (OECD). (2011). List of ICT Products and Services. Nigeria: Danmarks Statistik. 
INTERNATIONAL JOURNAL OF ACADEMIC RESEARCH IN BUSINESS AND SOCIAL SCIENCES

Vol. 10, No. 3, March, 2020, E-ISSN: 2222-6990 C 2020 HRMARS

Yinus, O., Oladejo, M. O., \& Akande, O. O. (2014). Impact of ICT Adoption on the Performance of Small and Medium Scale Food and Beverages Firms in Nigeria. International Journal of Advances in Management and Economics, 3(3), 45-52.

Olise, M. C., Anigbogu, T. U., Edoko, T. E., \& Okoli, M. I. (2014). Determinants of ICT adoption for improved SMEs Performance. American International Journal of Contemporary Research, 4(7), 163- 176.

Onyeaghala, O. H., \& Anele, C. A. (2014). Globalization: effects on small-scale business development in Nigeria. International Journal of Economics, Commerce and Management, II (5), 1-17.

Oyedele, O., Kareem, T. S., \& Akanbi, F. K. (2016). Globalization and small and medium enterprises development in Nigeria: evidence from Lagos, Nigeria. International Journal of Economics and Business Management, 2(4), 22-29.

Ramoni, S. A. \& Adepoju, B. A. (2018). Effects of Information and Communication Technology adoption on the operation of modern retail outlets in metropolitan Kano, Nigeria. Nigeria Academy of Management for $12^{\text {th }}$ Technology Acceptance Model (TAM) Conference Proceedings.

Simon-Oke, O. O. (2020).Working Capital Management-Performance Relationship: A Study of Small and Medium Enterprises in Akure, Nigeria. International Journal of Economics, Commerce and Management, Vol. VIII, Issue 2, 386-396.

Small and Medium Enterprises Development Agency of Nigeria (SMEDAN) (2017). National Micro, Small and Medium Enterprises (NMSME) Survey Report.

Venkatesh, V., Morris, M. G., Davis, G. B., \& Davis, F. D. (2003).“User Acceptance of Information Technology: Toward a unified view", MIS Quarterly, 27(3), 425-478.

Wambaria, D. W., Kibas, P. B., \& Asienga, I. C. (2016).Determining business environment factors in ICT adoption by SMEs owners in rural Kenya. International Journal of Economic, Commerce and Management, IV (10), 1180-1196. 